\title{
THE UNIDROIT PRINCIPLES OF CONTRACT LAW; IS THERE ROOM FOR THEIR INCLUSION INTO DOMESTIC CONTRACTS?
}

\author{
Dr. Bruno Zeller ${ }^{*}$
}

\section{INTRODUCTION}

When the UNIDROIT Principles (the Principles) were published in 1994 they were considered to be "soft law" and hence not binding on the courts. ${ }^{1}$ However, these principles have demonstrated that they are offering concrete and worthwhile solutions and arguably are a move forward in harmonizing and unifying contract laws. Indeed, the intention of the UNIDROIT Working Groups was to "develop a set of norms best suited to accommodate the needs of the international commercial community." argue that it reflects "concepts to be found in many, if not all, legal systems." As a result the Principles are not: "a rigid and limitative legal source but instead leave considerable room for flexibility, either to accommodate specific provisions to further individual parties' interest in their private dealings, or to promote national trade and economic policies. ${ }^{4}$ This makes the Principles a unique tool to be adapted into any contract and arguably protect the parties' just expectations arising from their contract. ${ }^{5}$

Significantly, an extensive body of academic writing and reported case law has shown that the Principles are a practical solution to the interpretation and application of contracts. ${ }^{6}$ The Principles have impacted in a significant way specifically on the solution of disputes in arbitration. ${ }^{7}$ Furthermore in 2004 a new edition of the Principles has been published enlarging the field of impact beyond simple contractual laws.

* Dr. Bruno Zeller is a Professor at Victoria University's School of Law.

1. Ole Lando, Principles of European Contract Law and UNIDROIT Principles: Moving form Harmonisation to Unification?, 8 UNIF. L. Rev. (n.s.) 123, 123 (2003).

2. Bayu Seto Hardjowahono, The UNIDROIT Principles and the Law Governing Commercial Contracts in Southeast Asia, UnIf. L. Rev. (n.s.) 1005, 1005 (2002).

3. The Governing Counsel of UNIDROIT, Introduction to The UNIDROIT Principles of International Contracts (1994) [hereinafter UNIDROIT Principles].

4. Seto Hardjowahono, supra note 2, at 1011.

5. Id.

6. See UNILEX on CISG \& UNIDROIT Principles, available at www.unilex.info.

7. Id. 
This demonstrates that the Principles are responding to the needs of a globalised market and have taken on the mantle of a lex mercatoria. This issue has been specifically addressed in the preamble which suggests that the Principles may be applied when the parties agreed that the contract be governed "by general principles of laws the lex mercatoria or the like." Due to the extended application of the Principles in arbitration the argument can be advanced that the theoretical or soft law stage has passed and the Principles have entered into the phase of "case-hardened" law. Such a view is, however, not universally accepted. The argument is still advanced that the UNIDROIT Principles are not "real law" but "merely a collection of general acknowledged principles" and hence cannot replace applicable laws. Such arguments are not convincing as the Principles are increasingly applied in arbitration without much opposition. Furthermore, the European Regulation Proposal (Rome I) of December 2005 recommended that the UNIDROIT Principles will be authorized as being a possible choice when deciding the applicable contractual law. ${ }^{10}$

Despite the recognition of the UNIDROIT Principles - as far as litigation is concerned - reference to has only been made in obiter and furthermore only in limited cases.

\section{A. Application of the Principles}

Despite all the controversies the Principles have affected domestic law. The effect is that the Principles have influenced municipal law in some countries through transplantation and have also been used as a model in the modernisation of domestic laws, specifically the Contract Law of the People's Republic of China. ${ }^{11}$

As another example the Principles played a major role in the modernisation of the Estonian Law of Obligation. The Principles together with the CISG formed not only the basis for the drafting of sales laws but have "also been an important source for drafting [and underpinning] the general

8. UNIDROIT Principles, supra note 3, Preamble.

9. See Christiana Fountoulakis, The Parties' Choice of 'Neutral Law' in International Sales Contracts, 7 European Journal of Law Reform, 303, 322 (2005). See also specifically n.124 for further references on this matter.

10. Art. 3 of the Proposal for a Regulation of the European Parliament ane the Council on the law applicable to contractual obligations (Rome I), COM(2005) 650 final, 2005/0261 (COD).

11. See Huang Dahan, The UNIDROIT Principles and their Influence in the Modernisation of Contract Law in the People's Republic of China, 8 UnIF. L. Rev. (n.s.) 107, 107 (2003). 
provisions" such as breach of contract. ${ }^{12}$ Therefore, the contemplation rule that is the foreseeability of loss has become a cornerstone in the Estonian domestic Law of Obligations. ${ }^{13}$

Furthermore, courts have referred to the Principles on several occasions. It is specifically instructive to note the views expressed in Hideo Yoshimoto v. Canterbury Golf International Ltd., ${ }^{14}$ where the New Zealand Court of Appeal found it necessary to refer to the UNIDROIT Principles and the CISG as they grappled with difficulties in interpreting a contract. Specifically the advantages of article 4.3 of the Principles were explained as allowing the court a more realistic approach in the interpretation of contracts. However, the court did not apply the Principles or the CISG for that matter, as they were not prepared to go beyond these declarations. The court commented: "But while this Court could seek to depart from the law as applied in England and bring the law in New Zealand into line with these international conventions, I do not think it would be permitted to do so by the Privy Council." 15 Therefore, there is, arguably, sufficient evidence that domestic systems have engaged in considering the Principles in the process of "creeping" transplantation. Bonell points out that the Principles are useful as a means of interpreting and supplementing the otherwise applicable law in cross border transactions. ${ }^{16}$

This paper is not concerned how the Principles have influenced arbitral decisions or how transplantation will affect domestic contract law. Nor is this paper concerned with cross border transactions. Of interest is only the effect an express inclusion of the Principles - or just some provisions - would have on a domestic contract.

The starting point to this investigation is the well-established practice that a legal system is obliged to give meaning to express terms in a contract unless these terms are in breach of a mandatory law. The question, therefore, is whether a court would apply clauses which run contrary to well-established domestic legal principles such as the parol evidence rule. For the purpose of

12. Paul Varul, CISG: A Source of Inspiration for the Estonian Law of Obligations, 8 UNIF. L. REv. (n.s.) 209, 209 (2003).

13. Id. at 209-10.

14. [2001] 1 N.Z.L.R. 523, 547 (C.A.), available at http://cisgw3.law.pace.edu/cases/ $001127 \mathrm{ng} . \mathrm{html}$.

15. Id. at 547. It should be noted that the English Privy Council was still the highest Court of Appeal in the New Zealand Court Hierarchy; this changed in 2004.

16. Michael J. Bonell, The UNIDROIT Principles and Transnational Law, in The Practice of Transnational Law 23, 37 (Klaus P. Berger ed., 2001). 
this paper only the application of the parol evidence rule and hence article 4.3 of the Principles will be investigated. ${ }^{17}$

Simply put the question is whether the courts interpret and apply the Principles in a manner which was contemplated by the promoters. This paper will not investigate the result of an inclusion of the Principles if article 4.3 is not also part of the contractual terms. It is arguably correct to assume that in the absence of article 4.3 a domestic court would follow its own interpretative mandate and would ignore the interpretative mandate of the Principles. The reason arguably is that any express term would be interpreted with domestic principles in mind, as the court would simply follow established domestic principles of interpretation.

In sum, the interesting problem is whether express terms of a contract including interpretive ones will override the domestic contract law. It is understood that this paper is of rather theoretical nature in so far as Australasia $^{18}$ is concerned. An inclusion of the Principles as terms into a domestic contract has not yet eventuated. However, it is hoped that it will spark some interest and that it will expose the UNIDROIT Principles to further scrutiny and research and perhaps even widen its application among the business community.

\section{The UNIDROIT PRINCIPLES}

Undoubtedly the Principles have provided potential solutions to national courts as seen in Hideo Yoshimoto v. Canterbury GolfInternational Ltd. ${ }^{19}$ and others. However, it never went beyond an admission that the Principles represent best international practices. The problem-especially in New Zealand - was the fear that an appeal would overturn a decision based on the Principles. Arguably, the court was concerned that an alternative to the parol evidence rule would not be acceptable as it is not part of domestic law. It is

17. UNIDROIT Principles Article 4.3, Relevant Circumstances, states:

In applying Articles 4.1 and 4.2, regard shall be hard to all the circumstances, including

(a) preliminary negotiations between the parties;

(b) practices which the parties have established between themselves;

(c) the conduct of the parties subsequent to the conclusion of the contract;

(d) the nature and purpose of the contract;

(e) the meaning commonly given to terms and expressions in the trade concerned;

(f) usages.

18. This term refers to Australia and New Zealand.

19. [2001] 1 N.Z.L.R. at 547. 
a clear indication that model laws cannot be introduced into a domestic system without establishing a compelling reason to do so.

In arbitration, compelling reasons were found and the strength and, hence, application of the Principles is well established. Arguably, the reason is that in arbitration a common concept and a common language is easily understood and can be readily applied to many situations where laws of different countries would be in conflict. Most importantly, the conflict of laws problem is minimised and many arbitral procedural laws do allow the arbitrators to exercise a choice in the absence of an express choice of a governing law.

However, even in arbitration, the problem still is - as Lando so aptly described - that "[s]cholars who cultivate their own domestic garden greatly outnumber those of the new . . regime." ${ }^{20}$ The advantage of the Principles, like the CISG, simply is that its language is clear and, therefore, the regulations are free from detailed digressions and exceptions so frequently found in the common law.

The problem is and will remain so for a while that ethnocentricity is simply difficult to overcome, as judges will understandably apply what is familiar to them. The difficulty to change the "mindset" can be discovered in the earlier decisions involving the CISG, a mandatory law, where a lack of understanding led to wrong decisions.

The overcoming of the ethnocentric trap is even more difficult if a soft law ought to be taken into consideration. Importantly, the Principles do not represent the lowest common denominator but are based on old and tested features which have stood the test of time and, hence, they will not become obsolete. ${ }^{21}$ For that reason, the Principles are an instrument which courts can look to for guidance. The question though is how far will court look for and apply the Principles in a way the promoters intended it to be used. Unlike the CISG, which is a convention and once ratified becomes part of domestic law the Principles are merely "voluntary" in character.

The UNIDROIT Principles (2004) in the Preamble state the Purposes of the Principles. The introductory sentence reads: "These Principles set forth general rules for international commercial contracts." 22 On first reading therefore the Principles appear to be only applicable to, first international contracts and, secondly, commercial contracts. This suggests that those contracts which do not involve an "international" element, should not be able

20. Lando, supra note 1 , at 128.

21. Id. at 131 .

22. UNIDROIT Principles, supra note 3, Preamble. 
to rely on the Principles. The second proviso appears to be an exclusion of consumer contracts which are largely governed by mandatory domestic laws and as such freedom of contract is curtailed.

However, the Principles_- perhaps ambitiously_note that despite being conceived for international contracts, they nevertheless can also be applied to purely domestic contracts "subject to the mandatory rules of the domestic law." 23 Two aspects need to be considered: first, does the domestic law consider the parol evidence rule to be a default rule or a mandatory rule; and secondly, do the Principles indicate or explain what mandatory rules are.

The Principles are silent as to the meaning of mandatory laws. On the other hand a study of the Commission on European Contract Law is of assistance in the determination of mandatory laws. The Principles of European Contract Law devote two articles to this matter. Article 15:101 in brief states that a contract is of no effect if "it is contrary to principles recognised as fundamental." ${ }^{24}$ The fundamental principles envisaged in this article are not merely national concepts but internationally recognised principles of immorality, illegality and public policy to mention a few. ${ }^{25}$ Therefore it can be argued that a principle such as the parol evidence rule would not be considered to fall under this article.

Furthermore, Article 15:102 of the Principles of European Contract Law directly states that a contract has no effect if it infringes mandatory rules. ${ }^{26}$ The commentary suggests that this article in effect is only applicable to rules "or prohibitions expressly or impliedly making contracts null, void, voidable, annullable, or unenforceable in particular circumstances. ${ }^{27}$

In relation to the parol evidence rule it can be argued that it is a default rule and not a mandatory rule. The most powerful argument is by looking at the Sale of Goods (Vienna Convention) Acts. In essence with the introduction of the CISG some mandatory rules such as in the Evidence Act had to be amended in order to be compatible with the CISG. No amendments had to be made to the parol evidence rule. Furthermore, courts in Australia are adopting article 8 of the CISG which in essence is similar to article 4.3 of the Principles. It is safe to conclude that the parol evidence rule does not fall

23. Id. at 3 .

24. Commission on European Contract Law, Principles of European Contract Law: Part III 211 (Ole Lando et al. eds., 2003).

25. Id.

26. Id. at 213 .

27. Id. at 214 
under the category of mandatory rules - but as mentioned above — is a default rule.

This leads the argument back to what the Preamble to the Principles states-: "[the rules] shall be applied when the parties have agreed that their contract be governed by them." Of interest is also that the Preamble suggests that the Principles may be used "as a substitute for a domestic law otherwise applicable. ${ }^{28}$

\section{The Principles and Contract Law}

The proposition that the Principles can be applied in domestic law is not impossible. The Uniform Commercial Code in the 2001 revision redrafted article 1.302. The comment 2 to the article states:

... parties may vary the effect of the [UCC] code's provisions by stating that their relationship will be governed by recognized bodies of rules or principles applicable to commercial transactions. Such bodies of rules or principles may include for example those that are promulgated by intergovernmental authorities such as UNCITRAL or UNIDROIT . . . .

As Bonell commented the reference to the Principles in the UCC is contained in the principle of "freedom of contract" and not with the "parties' right to choose the applicable law." 29 Such distinction becomes significant only if provisions of the Principles are incompatible with domestic mandatory laws.

The problem however, as indicated above, is that chapter 4 of the UNIDROIT principles nullifies the domestic principle of constructing a contract. This presupposes of course that the contract does not contain a merger clause. Pursuant to article 2.1.17 of the Principles a contract which contains a merger clause the "writing completely embodies the terms on which the parties have agreed." ${ }^{\prime 30}$ Therefore these terms cannot be contradicted or supplemented by any other means such as pre- or post contractual conduct.

In brief the question is whether a court would give priority to the interpretive mandate of the Principles and not revert to the domestic parol evidence rule, as the contract is ostensibly one of a domestic nature. There are several articles within the Principles which need to be considered in addition to article 4.3.

28. UNIDROIT Principles, supra note 3, Preamble at 7.

29. Michael Joachim Bonell, Brendan Brown Lecture Series: UNIDROIT Symposium: Soft Law and Party Autonomy: The Case of the UNIDROIT Principles, 51 Loy. L. REv. 229, 238 (2005).

30. UNIDROIT Principles, supra note 3, Article 2.1.17. 
Article 4.1 does not pose any problems as it merely requests that a contract shall "be interpreted according to the common intention of the parties." ${ }^{\prime 31}$ There is no conflict with the parol evidence rule as both rules seek to establish the common intent of the parties. However article 4.3 deviates markedly from the parol evidence rule by first stating that both articles 4.1 and 4.2 must be interpreted by taking the relevant circumstances into consideration. These circumstances are:

a) preliminary negotiations, b) the established practices between the parties, c) the subsequent conduct of the parties, d) nature and purpose of the contract, e) the common meaning given to terms and $\mathrm{f}$ ) usage. ${ }^{32}$

The Principles, therefore, apply both the "subjective" test and the "reasonableness" test. ${ }^{33}$

Common law courts in general solved the interpretative problem by taking a stance which ostensibly promotes certainty and predictability in contract performance and is expressed as follows: "The primary rule is simply to ascertain the meaning of the language of the contract and therefore . . . evidence of the pre-contractual negotiations of the parties or their subsequent conduct cannot be used in aid of the construction of a written contract." ${ }^{34}$ In other words only the evidence of the written contract will be considered. Simply put the law of contract is not concerned with the subjective intent of parties. It only protects an expectation which, in an objective sense, is common to both parties. ${ }^{35}$ This view was confirmed in Investors Compensation Scheme Limited v. West Bromwich Building Society. ${ }^{36}$ Lord Hoffman in his influential judgment did not embrace the introduction of subjective intent. Indeed in principle three he argues that: "(3) The law excludes from the admissible background the previous negotiations of the parties and their declarations of subjective intent.. ${ }^{, 37}$ In the United States the Revised U.C.C article 2.202 also suggests that; "when the parties have a

31. Id. at Article 4.1.

32. Id. at Article 4.3.

33. Id.

34. Yoshimoto, [2000] 1 N.Z.L.R. at 539 (C.A.).

35. Lord Steyn, Contract Law: Fulfilling the Reasonable Expectations of Honest Men, 113 L.Q. REv. 433, 434 (1997).

36. [1998] 1 WLR 896 .

37. Id. at 912-13. 
written final agreement, that agreement may not be contradicted by parol evidence." ${ }^{38}$

However Lord Steyn admitted that a rule cannot be absolute and unqualified, as it would defeat the reasonable expectations of commercial men. ${ }^{39}$ Lord Hoffmann himself pointed out that the rule is not unqualified, as subjective intent is "admissible only in an action for rectification." 40 Interestingly, in Australia, Mason J. also pointed out that: "the prior oral argument of the parties being inadmissible in aid of construction, though admissible in an action for rectification. ${ }^{, 41}$ Put simply, the subjective test is in essence rejected if the contract needs to be constructed. The more expansive tests of the Principles are not mirrored in domestic law.

This in itself does not mean that courts cannot make use of and apply the Principles in an interpretation of a domestic contract. However, an important point needs to be considered. A court cannot rely on any domestic principles or precedent which would give guidance in this matter as jurisprudence simply is not available.

The point is that, despite the applicable law being domestic in nature, only international jurisprudence can be relied upon to assist the courts in their interpretation. In addition, the CISG, having been ratified, could also be viewed analogically as being of assistance. The CISG can be regarded as being domestic in nature as it forms part of municipal law. This is not new and does not pose any problem as courts already have grappled with and solved this problem.

\section{A. The Principles and International Contract Law}

Arguably an ethnocentric approach - that is a reliance on domestic law only-could be challenged. The Australian High Court has recognized that the "goal" of international law is the mandate of uniformity. The Principles could also be included into this regime as they are international in character. It is encouraging to note that the High Court understands that uniformity of law is an important feature which contributes towards certainty and predictability in international trade. Especially in the area of transplantation - in this case the Warsaw Convention - it has been recognized

38. Henry Deeb Gabriel, Contracts for the Sale of Goods: A Comparison of Domestic And International LaW 55 (Oceana Press 2004).

39. Steyn, supra note 35 , at 440 .

40. Investors Comp. Scheme Ltd., [1998] 1 W.L.R. at 912-13

41. Codelfa Const. Pty. Ltd. v. State Rail Auth. of NSW [1982] 149 C.L.R. 337, 352. 
that: "decision must be reached by this Court with close attention to any relevant developments of international law, including decisions of the municipal courts of other states parties." ${ }^{42}$ The Australian High Court went even further and clearly stated that "[n]o differentiation could be drawn on the basis that it was not obligatory for Australia to apply the language of the Warsaw Convention to domestic carriage by air within Australia." 33

The mere fact that the Warsaw Convention was transplanted into Australian domestic law was sufficient for the High Court to abandon ethnocentric interpretation in favor of an international one. Considering that the Principles are not a transplantation nor ratified as a treaty should not detract from their usefulness. Arguably a reason not to adopt an international interpretation would be difficult to maintain.

However this leads to another point which needs to be investigated. Considering that the Principles are not "home grown" and are not part of the domestic law, the question must be asked whether analogically recourse to private international law would yield a different result. The point is that in English private international law, a contractual clause cannot contain two competing applicable laws. ${ }^{44}$ Furthermore, the Contracts (Applicable Law) Act 1990 does not permit a non-country specific law to govern a contract. ${ }^{45}$ This would lead to the conclusion that the Principles would not be allowed to govern the contract or for that matter any aspects of the contract such as the interpretation of the contract.

Of importance in this analysis is the recent decision in Bank Shamil of Bahrain v. Beximco. ${ }^{46}$ In that particular contract one of the clauses stated, "[s]ubject to the principles of the Glorious Sharia'a, this Agreement shall be governed by and construed in accordance with the laws of England." ${ }^{, 7}$

Arguably by including the Principles into a domestic contract the same result could be achieved namely that the law of say Australia applies but the construction and possibly parts of the contact are subject to the Principles. At first glance such a clause would be enforceable by the fact that English and

42. Air Link Pty. Ltd. v. Paterson [2005] HCA 39 (Unreported, Gleason CJ, McHugh, Cummow, Kerby, Hayne, Callinan and Heydon JJ, 10 Aug. 2005) [40] (Kerby J)).

43. Id. at 49 .

44. I am indebted for this section to Jason Chuah, Reader in Commercial Law, University of Westminster UK. He presented a paper at the 3rd International Conference on Law and Commerce in Kuala Lumpur. His paper (on file with author) gave the inspiration to include this section.

45. See supra note $44, \boldsymbol{9} 40$.

46. Shamil Bank of Bahrain EC v. Beximco Pharm. Ltd. [2004] EWCA (Civ) 19.

47. Id. $\uparrow 1$. 
Australian courts have always been willing to apply a set of codified laws such as the Warsaw Convention into the contract as a paramount clause. ${ }^{48}$

Simply put it can be argued that the inclusion of the Principles into a contract is deemed to have satisfied the above test. The Principles or specified articles are an international set of rules which are apt to be incorporated into a contract and are sufficiently identifiable.

However, this conclusion is somewhat contradicted by the Rome Convention article 1(1) which states that the rules of this convention shall apply to contractual obligations in any situation involving a choice between the laws of different countries. Furthermore, article 3(3) "make[s] it clear that the convention as a whole only contemplates and sanctions the choice of the law of a country." ${ }^{, 49}$ The English Court of Appeal specifically noted that systems of law such as the lex mercatoria or general principles of law are excluded. As a result they rejected the Banks contention that the choice of law clause is enforceable. ${ }^{50}$ This finding would suggest that the Court of Appeal would have arguably also rejected the Principles.

However such a conclusion is not correct. The argument can be advanced that the Principles are to be distinguished from the lex mercatoria or "general principles of Law" insofar as they consist of a body of specifically discernable laws which are not couched in general language but are in "written" form hence applicable as any system of law would be. Furthermore it is not a choice between one system of law but rather an application of general terms and conditions which are specific and not general in nature as in the above case. The reference to the law of Sharia' as stated in general terms, is of a broad nature and indeterminable as to which parts are applicable.

However, there is a distinction between a general reference to a foreign body of law - whether black letter law of soft law - and the incorporation of specific terms of such a body into a contract.

Indeed the court of appeal pointed out that:

The doctrine of incorporation can only sensibly operate where the parties have by the terms of their contact sufficiently identified specific "black letter" provisions of a foreign law or an international code or set of rules apt to be incorporated as terms of the relevant contract such as particular article or articles of the French Civil Code or the Hague Rules. ${ }^{51}$

\footnotetext{
48. See Air Link Pty. Ltd., [2005] HCA 39 at 940.

49. Bank of Shamil of Bahrain, [2004] EWCA (Civ) 19 at 48.

50. $I d$.

51. Id. $ๆ 51$
} 
The conclusion, therefore, is that the Principles incorporated as terms of the contract only have effect as a matter of contract. ${ }^{52}$ Hence parties making an express choice, either of a foreign law or an internationally recognisable set of rules, will have their choice recognised and applied within the governing law of the contract. Therefore Australian domestic law will be applied as the governing law in the application of the terms of the contract. Put simply a court will give effect to terms if either the Principles as a whole or clearly identifiable parts of the principles are included into the contract. It should be clear by now that such choices cannot be inconsistent with mandatory laws of the forum.

\section{CONCLUSiON}

As pointed out above this paper is merely an exploration of possibilities in contracting which has been brought about by taking a different view on contractual obligations. This view is based on comparative work which has mainly concentrated on legal principles to be applied in international trade but - as argued - can also be extended to domestic situations.

The problem is not whether the Principles are applicable - that is can they be validly incorporated into contracts - but rather whether domestic courts are able and willing to implement contracts in the light of the interpretative mandate which basically runs contrary to the domestic parol evidence rule. It has been argued that the parol evidence rule is not a mandatory law hence it can be replaced with different rules on which the contracting parties have agree upon such as the UNIDROIT Principles.

Two conflicting forces would be at play here namely the duty of the court to apply contractual clauses and the principle that decisions of a different jurisdiction can only be persuasive. Of special interest - and not discussed in this paper-is whether an application of only domestic precedent would allow an aggrieved party to appeal on a point of law.

Hopefully the application of the UNIDROIT principles does not suffer the same fate as the application of foreign law. A study of 40 American decisions showed that in 36 cases the foreign law was either wrongly applied or the result was highly doubtful. ${ }^{53}$

The conclusion simply is that the outcome of an application of a contract relying on the UNIDROIT Principles depends on the ability of a domestic

52. $I d .950$.

53. Lando, supra note 1, at 126. 
court to recognize that they need to step outside the domestic system and simply not apply the parol evidence rule. 